\title{
PERMEABILIZATION, CELL WALL ULTRASTRUCTURE, AND GERMINATION OF BASIDIOSPORES OF THE ECTOMYCORRHIZAL FUNGUS Pisolithus microcarpus TREATED WITH DIFFERENT COMMERCIAL BRANDS OF BLEACH
}

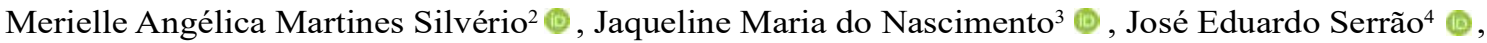 \\ Marcos Rogério Tótola ${ }^{5}$ a and Maurício Dutra Costa ${ }^{5 *}$ 두
}

\footnotetext{
${ }^{1}$ Received on 23.07.2020 accepted for publication on 01.02.2021.

${ }^{2}$ Universidade Estadual Paulista Júlio de Mesquita Filho, Programa de Pós-Graduação em Educação Para a Ciência, São Paulo, SP - Brasil. E-mail: <merielleangelica@gmail.com>.

${ }^{3}$ Universidade Federal de Viçosa, Programa de Pós-Graduação em Microbiologia Agrícola, Viçosa, MG -Brasil.E-mail:<jaquelinemaria92@ hotmail.com>

${ }^{4}$ Universidade Federal de Viçosa, Departamento de Biologia Geral, Viçosa, MG - Brasil. E-mail: <jeserrao@ufv.br>.

${ }^{5}$ Universidade Federal de Viçosa, Departamento de Microbiologia, Viçosa, MG - Brasil. E-mail: <totola@ufv.br> and <mdcosta@ufv.br>. *Corresponding author.
}

\begin{abstract}
Basidiospores of the ectomycorrhizal fungus Pisolithus microcarpus have an impermeable cell wall, a characteristic that is possibly related to the low germination percentages of these propagules, which makes it difficult to obtain monokaryons and use these spores in inoculants. The objective of this study was to evaluate the effect of different concentrations of commercial bleach on the permeabilization of $P$. microcarpus basidiospores and to analyze the alterations caused in the cell wall ultrastructure and the viability and germination capacity of these propagules. Fungal basidiospores were collected in eucalyptus plantations and permeabilized using different bleach concentrations and exposure times. The basidiospores were then analyzed by scanning and transmission electron microscopy. The percentage of permeabilized basidiospores varied with the commercial brand, bleach concentration, and exposure time. Basidiospores of different basidiocarps differed in susceptibility to permeabilization treatment with bleach. Changes in the ultrastructure of permeabilized basidiospores were observed at bleach concentrations of 15 and $50 \%$ for an exposure time of $40 \mathrm{~s}$, with surface changes and loss of the spicules of the outermost layer of the wall. After permeabilization with $5 \%$ bleach for $40 \mathrm{~s}, 80 \%$ of the permeabilized spores were viable, resulting in the production of fungal colonies after 15 days of incubation of these propagules in the presence of Corymbia citriodora. However, the germination percentage obtained, $0.001 \%$, was similar to that of non-permeabilized basidiospores, indicating that other factors, besides cell wall permeability, are determinant for the germination process.
\end{abstract}

Keywords: Ectomycorrhiza, Inoculant, Eucalyptus.

\section{PERMEABILIZAÇÃO, ULTRAESTRUTURA DA PAREDE CELULAR E GERMINAÇÃO DE BASIDIÓSPOROS DO FUNGO ECTOMICORRÍZICO Pisolithus microcarpus TRATADOS COM DIFERENTES MARCAS COMERCIAIS DE AGUA SANITARIA}

RESUMO - Basidiósporos do fungo ectomicorrízico Pisolithus microcarpus apresentam parede celular impermeável, característica possivelmente relacionada às baixas porcentagens de germinação desses propágulos, o que dificulta a obtenção de monocários e a utilização desses esporos em inoculantes. O objetivo deste estudo foi avaliar o efeito de diferentes concentrações de água sanitária comercial na permeabilização dos basidiósporos de P. microcarpus e analisar as alterações causadas na ultraestrutura da parede celular, na viabilidade e na capacidade germinativa desses propágulos. Basidiósporos fúngicos foram coletados em plantações de eucalipto e permeabilizados utilizando-se diferentes concentrações de água sanitária e tempos de exposição. Os basidiósporos foram então analisados por microscopia eletrônica de varredura e de transmissão. A

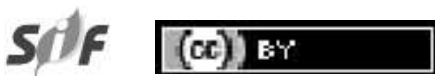

Revista Árvore 2021;45:e4509 http://dx.doi.org/10.1590/1806-908820210000009 


\begin{abstract}
porcentagem de basidiósporos permeabilizados variou com a marca comercial, concentração de água sanitária e o tempo de exposição. Basidiósporos de diferentes basidiocarpos diferiram na suscetibilidade ao tratamento de permeabilização com água sanitária. Alterações da ultraestrutura dos basidiósporos permeabilizados foram observadas nas concentrações de 15 e 50 \% de água sanitária pelo tempo de exposição de $40 \mathrm{~s}$, com mudanças de superfície e perda das espículas da camada mais externa da parede. Após a permeabilização com água sanitária a $5 \%$ por $40 \mathrm{~s}, 80 \%$ dos esporos permeabilizados encontravam-se viáveis, resultando na produção de colônias fúngicas após 15 dias de incubação desses propágulos na presença de Corymbia citriodora. No entanto, a porcentagem de germinação obtida: 0,001\%, foi semelhante à de basidiósporos não-permeabilizados, indicando que outros fatores, além da permeabilidade da parede celular, são determinantes para o processo de germinação.

Palavras-Chave: Ectomicorriza, Inoculante, Eucalyptus.
\end{abstract}

\section{INTRODUCTION}

Ectomycorrhizas are symbiotic associations between soil basidiomycete fungi and roots of tree plants, contributing to the promotion of plant growth and mitigation of biotic and abiotic stresses (Smith \& Read, 2010; van der Heijden et al., 2015). These associations are frequent in forest species of economic interest, such as eucalyptus (ABRAF, 2013). Among the fungi that form ectomycorrhizas, those of the genus Pisolithus stand out, being associated with roots of several species of gymnosperm and angiosperm plants in several regions of the globe, including Brazil (Martin et al., 2002).

The germination of ectomycorrhizal fungal spores has been studied in several species, and the germination percentages reported in the literature are generally low (Costa, 2002; Pereira, 2004; Pereira et al., 2017). This fact prevents the production of monokaryotic strains intended for studies on the genetics of the ectomycorrhizal association, the application of mutagenesis techniques to spores and the production of spore-based inoculants to be used in seedling production in forest nurseries (Costa, 2002; Pereira et al., 2017). For Pisolithus, the germination percentage of basidiospores ranges from 0.001 to $0.38 \%$ (Kope \& Fortin, 1990; Costa, 2002; Pereira, 2004). In part, recalcitrance to germination has been attributed to the impermeability of the cell wall of the spores of this fungus.

Fungal cell wall is composed of glycoproteins and polysaccharides, mainly glucans and chitin (Gow et al., 2017; Ruiz-Herrera \& Ortiz-Castellanos, 2019). Chitin is a linear polymer formed by $\mathrm{N}$-acetyl glucosamine molecules, joined by glucosidic bonds. The $\beta-1,4$ bond of this polysaccharide form microfibrils in the extracellular space that contribute to the rigidity of the cell wall (Ruiz-Herrera et al., 1996; Gow et al., 2017; Ruiz-Herrera \& OrtizCastellanos, 2019). Among the proteins present in the cell wall, hydrophobins stand out, which are small and moderately hydrophobic proteins that contain eight conserved cysteine residues (Ruiz-Herrera \& Ortiz-Castellanos, 2019), being strongly linked to cell wall polymers (Vries et al., 1993; Ruiz-Herrera \& Ortiz-Castellanos, 2019). Glycoproteins are modified proteins of the wall by the binding of oligosaccharides during translocation and cell secretion (Gow et al., 2017; Ruiz-Herrera \& Ortiz-Castellanos, 2019).

In studies with the species P. microcarpus, aiming at the description of the process of basidiosporogenesis and meiosis, changes in the fluorescence emission pattern of the basidiospores throughout development were verified, which was attributed to the deposition of different wall layers in the spores (Campos \& Costa, 2010a). It has been suggested that, similarly to P. tinctorius, the basidiospores of P. microcarpus also have four wall layers (Campos \& Costa, 2010a). It has been hypothesized that the structure of the cell wall, associated with its hydrophobicity, could be related to the recalcitrance of the basidiospores of this fungal species to germination (Costa, 2002; Campos \& Costa, 2010a; Godinho, 2011). Thus, the permeabilization of the cell wall could allow the entry of signals that induce the germination of spores produced by eucalyptus (Costa, 2002).

The permeabilization of the cell wall of fungal spores can be performed by chemical methods, involving the use of lytic enzymes or inorganic substances (Costa, 2002; Godinho, 2011). The treatment of basidiospores with sodium hypochlorite present in commercial formulations of bleach

Revista Árvore 2021;45:e4509 
promoted the permeabilization of the cell wall, making it possible to study the different reserve compounds contained in the basidiospores (Godinho, 2011). However, the effects of this permeabilization process on the ultrastructure of the wall, as well as the viability and germination capacity of the spores, are not known. Thus, the objective of this study was to evaluate the efficiency of commercial bleach in the permeabilization of the cell wall of $P$. microcarpus basidiospores and the effects of this treatment on the ultrastructure, viability and germination capacity of these propagules in the presence of $C$. citriodora.

\section{MATERIAL AND METHODS}

\subsection{Microorganism and storage conditions}

The study was carried out at the Laboratory of Mycorrhizal Associations of the Department of Microbiology, located at the Institute of Biotechnology Applied to Agriculture (BIOAGRO) of the Federal University of Viçosa (UFV), Viçosa, MG, Brazil. Basidiocarps of P. microcarpus were collected in Corymbia spp. forests in the Forestry Sector of UFV, from August 2012 to June 2013. The basidiocarps were washed externally with distilled water and immersed in $70 \%$ ethanol for $1 \mathrm{~min}$, for superficial disinfestation, and air dried in a laminar flow cabinet until the solution evaporated. The basidiocarps were sectioned longitudinally with a scalpel, and the spores, collected with sterile spatula, were kept in a refrigerator.

\subsection{Permeabilization of basidiospores with bleach}

Half a gram of basidiospores was suspended in $1 \mathrm{~mL}$ of Tween 80 at $0.5 \%$. The suspension was centrifuged at 10,000 rpm for $8 \mathrm{~min}$ and washed three times with distilled water. Finally, the basidiospores were resuspended in distilled water and subjected to the permeabilization treatment with bleach (Costa, 2002). Five brands of bleach, containing 2 to $2.5 \%$ of active chlorine (w/w), were tested as to their capacity of permeabilization of $P$. microcarpus basidiospores from a single basidiocarp. The bleach brands were identified with numbers from 1 to 5 . The concentrations of bleach used were 15 and $50 \%$ for a time of $40 \mathrm{~s}$ (Godinho, 2011). 250- $\mu \mathrm{L}$ aliquots of the suspension of basidiospores were transferred to 1.5-mL Eppendorf tubes and treated with $250 \mu \mathrm{L}$ of bleach solutions, in order to obtain the final concentrations above.
Treatment was interrupted by the addition of $500 \mu \mathrm{L}$ of sodium thiosulfate at $0.14 \mathrm{~mol} \mathrm{~L}^{-1}$. The basidiospores were centrifuged at 10,000 rpm for $2 \mathrm{~min}$, washed twice in distilled water and stained with $250 \mu \mathrm{L}$ of Sudan Black B dye at $2 \%(\mathrm{w} / \mathrm{v})$. To determine the percentage of permeabilized basidiospores, a 10$\mu \mathrm{L}$ aliquot of each suspension of stained spores was mounted between slide and coverslips and observed under light microscope, counting five fields of each slide. Basidiospores stained with Sudan Black B were considered permeabilized. The means were compared by the Tukey test at $5 \%$ probability.

\subsection{Permeabilization of basidiospores from different basidiocarps}

After collecting 10 basidiocarps and cleaning their surfaces with distilled water, the basidiospores were harvested and subjected to permeabilization procedures at concentrations of 15 and $50 \%$ of bleach for $40 \mathrm{~s}$ (Godinho, 2011), staining with Sudan Black $\mathrm{B}$ at $2 \%(\mathrm{v} / \mathrm{v})$ and determination of the percentage of permeabilization, as described in item 2.2. The experiment was set up with three replicates and the obtained data were subjected to analysis of variance. Treatment means of each treatment were compared the Tukey test test at $5 \%$ probability.

\subsection{Optimization of basidiospore cell wall permeabilization conditions}

The optimization of the permeabilization conditions was performed for one of the basidiocarps collected, following the procedures described in item 2.2. The final concentrations of bleach tested were $0,2.5,5,10,15,20,25,30,35,40,45$ and $50 \%$ $(\mathrm{v} / \mathrm{v})$. The times of exposure to the permeabilization agent were 5, 10, 20, 30, 40, 50, 60, 70 and $80 \mathrm{~s}$. The experiment was set up in a factorial scheme, with three replicates, and the obtained data were subjected to regression analysis.

\subsection{Ultra-morphology of basidiospore cell wall determined by scanning and transmission electron microscopy}

A sample of basidiospores from a single basidiocarp was permeabilized with bleach at 15 and $50 \%$ for $40 \mathrm{~s}$, fixed in $10 \%$ formalin (v/v) for $2 \mathrm{~h}$ and, subsequently, subjected to drying in an oven at $40{ }^{\circ} \mathrm{C}$ for $24 \mathrm{~h}$. A control, without permeabilization, was also included. The basidiospores were metallized with 150- $\mathrm{A}^{\mathrm{o}}$-thick gold layer and observed in a LEO VP1430

Revista Árvore 2021;45:e4509 
scanning electron microscope. The basidiospores were also subjected to transmission electron microscopy. For this, the examination of cell wall ultrastructure followed the procedure described by Mims \& Thurston (1979) and Webster (2007) modified by the processing with 5 pulses of thermal shock for $40 \mathrm{~s}$ iin a microwave, $700 \mathrm{~W}$, and $5 \mathrm{~min}$ under refrigeration, after each step below: basidiospores permeabilized or not were fixed in $2.5 \%$ glutaraldehyde solution and in $0.2 \mathrm{M}$ sodium cacodylate, $\mathrm{pH} 7.2$, for $4 \mathrm{~h}$ at room temperature, and were subsequently resuspended in $0.1 \mathrm{~mol} \mathrm{~L}^{-1}$ sodium cacodylate for $5 \mathrm{~min}(2 \mathrm{X})$. The suspension was centrifuged and resuspended in $\mathrm{OsO}_{4}$ ( $1 \%$ ) for $2 \mathrm{~h}$ at room temperature. After this period, the solution was resuspended in $500 \mu \mathrm{L}$ of $0.1 \mathrm{~mol}$ $\mathrm{L}^{-1}$ sodium cacodylate, centrifuged and subsequently kept in $70 \%$ alcohol for $24 \mathrm{~h}$ under refrigeration. The basidiospores were dehydrated dehydrated using an ethanol series of $80,90,95$ and $100 \%$ for 20 min in each concentration. The dehydrated samples were included in LR White resin and subjected to microtomy. The sections were stained with $1 \%$ uranyl acetate and lead citrate and analyzed under a Zeiss EM109 transmission electron microscope.

\subsection{Viability and germination of permeabilized basidiospores}

Basidiospores from a selected basidiocarp were permeabilized by exposure to bleach at 5, 10, 15, 30 and $50 \%$ for $40 \mathrm{~s}$. For verifying the viability, the basidiospores were stained with the Live/ Dead Fungal Light Yeast Viability Kit, Molecular Probes $^{\circledR}$, Life Technologies ${ }^{\mathrm{TM}}$, as instructed by the manufacturer. Cells with intact membrane emit green fluorescence, while cells with damaged membrane emit red fluorescence. The samples were analyzed under an Olympux BX 50 fluorescence microscope with accessories for Y-F epifluorescence, and the images were captured with an Olympus PM - C35DX digital camera. The experiment was set up with three replicates and the obtained data were subjected to analysis of variance. Means were compared by the Tukey test at $5 \%$ probability.

Newly collected basidiospores were permeabilized as described in item 2.2 by the treatment with bleach at the concentration of $10 \%$ for $40 \mathrm{~s}$. The time of $40 \mathrm{~s}$ was the one that made it possible to eliminate contaminant microorganisms and maintain the highest percentage of viable basidiospores, $35 \%$. $100-\mu \mathrm{L}$ aliquots of a suspension containing $5 \times 10^{6}$ $\mathrm{mL}^{-1}$ permeabilized spores were spread on $25 \mathrm{~mL}$ of modified Melin-Norkans medium (Marx, 1969), supplemented with $2 \mathrm{~g} \mathrm{~L}^{-1}$ of activated carbon, in order to obtain a final density of $5 \times 10^{5}$ spores per dish. One seedling of $C$. citriodora, one week old and free of contamination, was placed in the middle region of the dish containing the spores. $C$. citriodora seedlings free of contamination were obtained according to the procedures of Pereira (2004). The Petri dishes were sealed with PVC film and incubated in a growth chamber at $25{ }^{\circ} \mathrm{C}$ and with $16 \mathrm{~h}$ of light $(200 \mu \mathrm{mol}$ $\left.\mathrm{m}^{-2} \mathrm{~s}^{-1}\right)$. To determine the germination percentage of basidiospores, the appearance of colonies was evaluated every 2 days by direct observation.

\section{RESULTS}

\subsection{Permeabilization of basidiospores with bleach}

The bleach brands tested differed ias to their efficiency at permeabilizing the cell wall of $P$. microcarpus basidiospores (Figure 1). At bleach concentrations of 15 and $50 \%$ for $40 \mathrm{~s}$, brand 1 permeabilized 12 and $78 \%$ of the treated basidiospores, respectively. Given its higher permeabilization efficiency, the bleach brand 1 was chosen to be used in all other experiments carried out in this study.

\subsection{Permeabilization of basidiospores from different basidiocarps}

The basidiospores from different basidiocarps showed different levels of susceptibility in relation to the treatment of permeabilization with bleach (Figure 1). In the treatment with $15 \%$ bleach and $40 \mathrm{~s}$, the percentage of permeabilized basidiospores ranged from 4.5 to $26 \%$, depending on the basidiocarp. In the treatment with $50 \%$ bleach, for the same time of exposure, the values ranged from 70 to $95 \%$.

\subsection{Optimization of permeabilization conditions of the cell wall of $P$. microcarpus basidiospores}

The percentage of $P$. microcarpus basidiospores permeabilized with bleach was proportional to the concentration and time of exposure to the permeabilizing agent (Figure 2). The highest percentage of permeabilization ( $88 \%$ ) was obtained by combining the concentration of $50 \%$ bleach with the time of $80 \mathrm{~s}$ (data not shown). 

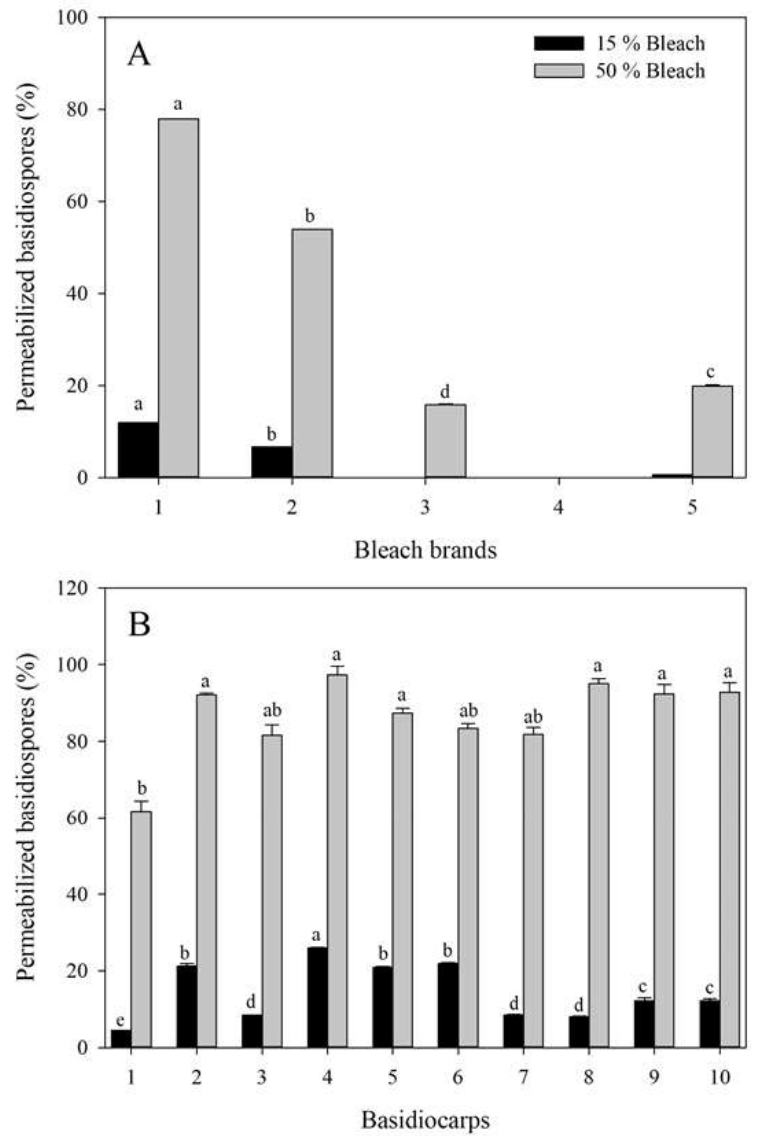

Figure 1-Effect of different bleach brands on the permeabilization of Pisolithus microcarpus basidiospores from a single (A) or different (B) basidiocarps at concentrations of 15 and $50 \%$ of bleach for a period of 40 seconds. For each concentration, bars with the same letter do not differ from each other by Tukey test at $5 \%$ probability level.

Figura 1 - Efeito de diferentes marcas de água sanitária na porcentagem de permeabilização de basidiósporos de Pisolithus microcarpus oriundos de um único $(A)$ ou de diferentes basidiocarpos (B) nas concentrações de 15 e $50 \%$ de água sanitária, por um periodo de 40 segundos. Para cada concentração, barras com a mesma letra não diferem entre si pelo teste de Tukey a 5 $\%$ de probabilidade.

\subsection{Ultra-morphology of basidiospore cell wall determined by scanning and transmission electron microscopy}

Scanning microscopy revealed changes in the spicules contained in the outer layer of the cell wall of the permeabilized basidiospores (Figure $3)$. These changes were more pronounced at the highest concentration of bleach used $(50 \%)$, with exposure time of $40 \mathrm{~s}$, a condition that led to partial

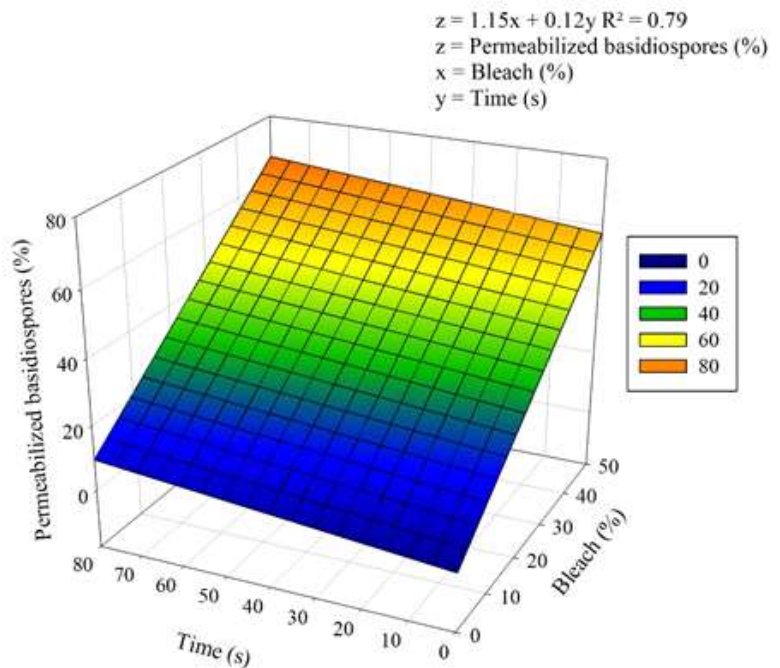

Figure 2 - Percentage of Pisolithus microcarpus basidiospores permeabilized with bleach (brand 1) at different concentrations and exposure times. The original active chlorine concentration of the commercial product used was 2 to $2.5 \%(\mathrm{w} / \mathrm{w})$

Figura 2-Porcentagem de basidiósporos de Pisolithus microcarpus permeabilizados com água sanitária (marca 1) em diferentes concentrações e tempos de exposição. A concentração de cloro ativo original do produto comercial utilizado foi de 2 a 2,5\% (p/p).

or total loss of the spicules (Figure 3 and 4). The analysis of the ultrastructure of $P$. microcarpus basidiospores by transmission electron microscopy revealed the following aspects of the cell wall: mature basidiospores have a cell wall consisting of four layers, the outermost, $\mathrm{L}_{1}$, is electron-dense and ornated with spicules on its surface, followed by an electron-transparent inner layer, $\mathrm{L}_{2}$. The third layer, $\mathrm{L}_{3}$, is also electron-dense and the innermost layer, $\mathrm{L}_{4}$, is electron-transparent (Figure 4).

\subsection{Viability and germination of permeabilized basidiospores}

The viability of the basidiospores was reduced with the increase in the bleach concentration used in the permeabilization procedure (Figures 5). The use of bleach at concentrations of 5, 10, 15, 30 and 50 $\%$ for $40 \mathrm{~s}$ resulted in $80,35,19$ and $2 \%$ of viable basidiospores, respectively. In the treatment of bleach $(50 \%)$ for $40 \mathrm{~s}$, no basidiospore remained viable (Figure 5).

It was possible to obtain fungal colonies from the germination of basidiospores permeabilized with $10 \%$ bleach for $40 \mathrm{~s}$, with $35 \%$ viability. This 

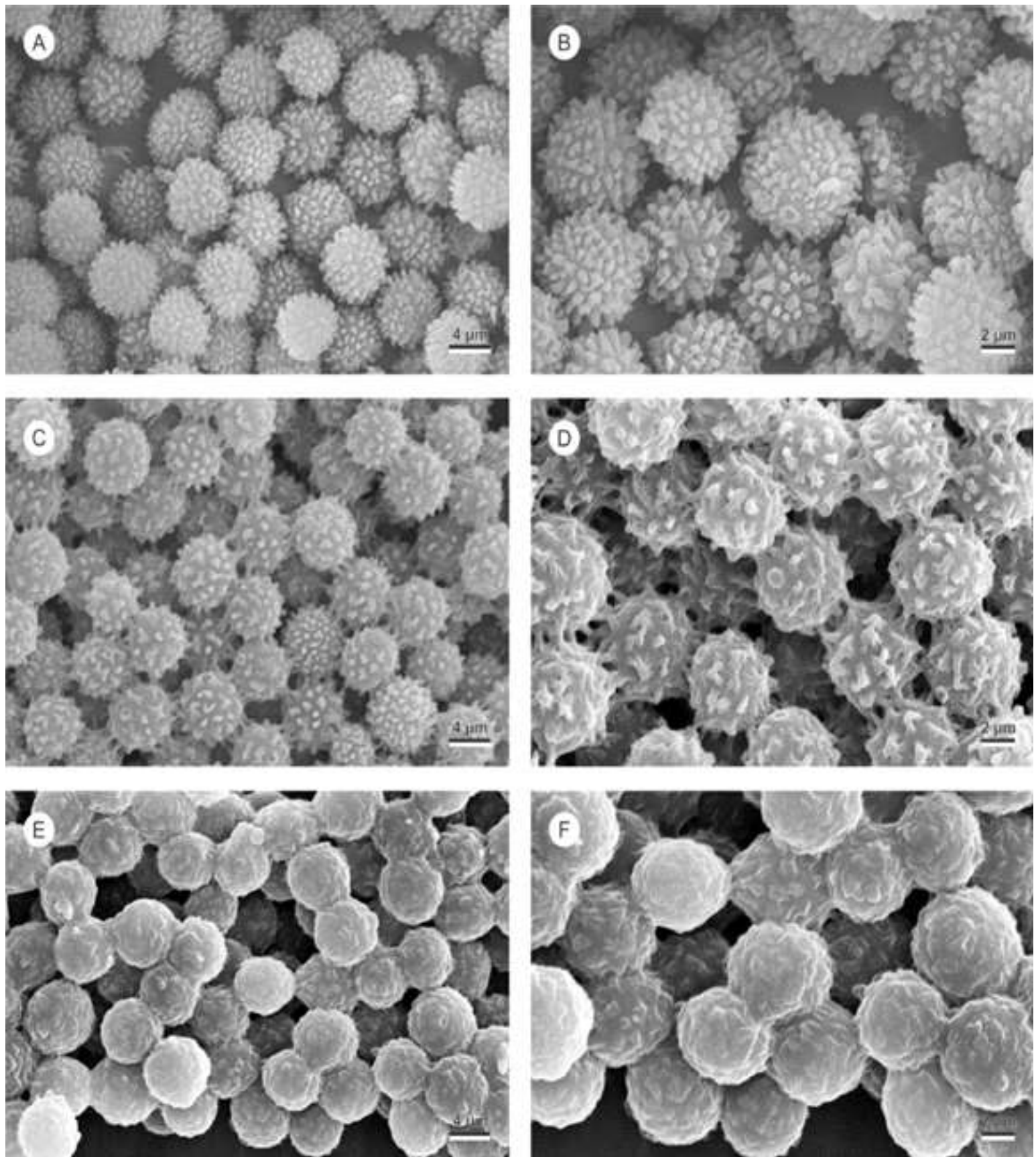

Figure 3 - Electronic scanning micrograph of Pisolithus microcarpus basidiospores intact or permeabilized with sbleach brand 1. (A and B) Basidiospores of control treatment, not permeabilized. Notice the ornamentation of the basidiospore surface with spicules. (C and D) Basidiospores permeabilized with bleach at $15 \%$ for $40 \mathrm{~s}$. Notice the presence of spicules with altered morphology. (E and F) Basidiospores permeabilized with $50 \%$ bleach for $40 \mathrm{~s}$. Notice the partial or total disappearance of the spicules, with changes in the morphology of the basidiospores.

Figura 3 - Micrografia eletrônica de varredura de basidiósporos de Pisolithus microcarpus intactos ou permeabilizados com soluções de água sanitária marca 1. (A e B) Basidiósporos do tratamento controle, não permeabilizados. Notar a ornamentação da superficie do basidiósporo com espiculas. (C e D) Basidiosporos permeabilizados com água sanitária a $15 \%$ por $40 \mathrm{~s}$. Notar a presença de espículas com morfologia alterada. (E e F) Basidiósporos permeabilizados com água sanitária a $50 \%$ por $40 \mathrm{~s}$. Notar o desaparecimento parcial ou total das espiculas, com alterações na morfologia dos basidiósporos.

Revista Árvore 2021;45:e4509 

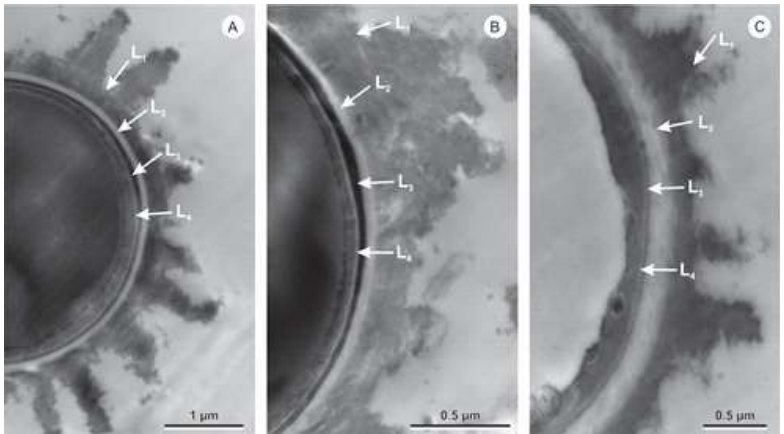

Figure 4 - Transmission electron micrograph of Pisolithus microcarpus basidiospores, intact or permeabilized with bleach. (A) Basidiospore of control treatment, not permeabilized. Notice the cell wall stratified into 4 layers $\left(\mathrm{L}_{1}, \mathrm{~L}_{2}, \mathrm{~L}_{3}\right.$ and $\left.\mathrm{L}_{4}\right)$ and the presence of intact spicules. (B) Basidiospore permeabilized with bleach at $15 \%$ for 40 s. Observe the presence of partially degraded spicules. (C) Basidiospore permeabilized with $50 \%$ bleach for 40 s. Observe partially degraded spicules.

Figura 4-Micrografia eletrônica de transmissão de basidiósporos de Pisolithus microcarpus intactos ou permeabilizados com água sanitária. (A) Basidiósporo do tratamento controle, não permeabilizados. Notar a parede celular estratificada em 4 camadas $\left(L_{,}, L_{2}, L_{3}\right.$ e $\left.L_{2}\right)$ e a presença de espiculas intactas. (B) Basidiosporo permeabilizado com água sanitária a $15 \%$ por $40 \mathrm{~s}$. Observar a presença de espículas parcialmente degradadas. $(C)$ Basidiósporo permeabilizado com água sanitária a $50 \%$ por 40 s. Observar espículas parcialmente degradadas.

treatment was also effective for eliminating microbial contaminants that are naturally found in basidiocarps. The first colonies of $P$. microcarpus from the basidiospores with permeabilized cell wall appeared between the 15th and 18th day of incubation of the basidiospores in the presence of the host plant $C$. citriodora. The fungal colonies emerged close to the roots. The percentage of germination was low, 0.001 $\%$.

\section{DISCUSSION}

In this study, the cell wall of $P$. microcarpus basidiospores was successfully permeabilized with commercial bleach. The choice of this agent aimed to reduce the costs of permeabilization of spores for the production of commercial inoculants and eliminate contaminant bacteria naturally present in the basidiospores. Previous tests performed with the pure sodium hypochlorite reagent, under the same conditions, resulted in a low percentage of permeabilized basidiospores (data not shown), indicating that other components of the reagent act jointly in the weakening of the cell wall. The differences

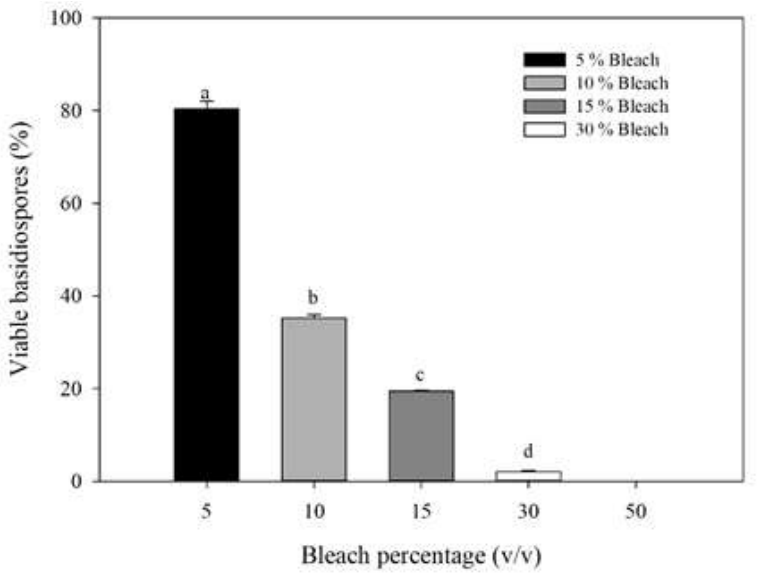

Figure 5 - Percentage of viable Pisolithus microcarpus basidiospores after cell wall permeabilization with bleach brand 1 at concentrations of 5, 10, 15, 30 and 50 $\%$ for $40 \mathrm{~s}$. Bars with the same letter do not differ from each other by the Tukey test at $5 \%$ probability.

Figura 5 - Porcentagem de basidiósporos de Pisolithus microcarpus viáveis após a permeabilização da parede celular com água sanitária marca 1 nas concentrações $5,10,15,30$ e $50 \%$ por $40 \mathrm{~s}$. Barras com mesma letra não diferem entre si pelo teste de Tukey a $5 \%$ de probabilidade.

of permeabilization found for each bleach brand may be related to different chemical compositions. The active chlorine content, described in the packaging of the 5 brands tested, was in accordance with the level required by legislation, ranging from 2.0 to $2.5 \%(\mathrm{w} / \mathrm{w})$ (INMETRO, 2013). Brand 1 contained sodium hydroxide and sodium carbonate as additional components to sodium hypochlorite and water, while brands 2, 3, 4 and 5 consisted only of sodium hypochlorite and water. Sodium hydroxide and sodium carbonate, as well as sodium hypochlorite, have antimicrobial action (Siqueira Jr \& Lopes, 1999; Adner \& Zetterlund, 2002; Estrela et al., 2006). The synergistic action of these components associated with the active chlorine of sodium hypochlorite may justify the higher permeabilization efficiency promoted by brand 1 .

The variation in the efficiency of commercial products in permeabilizing the cell wall of the basidiospores may also be related to the period of collection of basidiocarps and the maturation stage of their basidiospores (Campos \& Costa, 2010b), factors that can influence the susceptibility of these propagules to the treatment of permeabilization. The maturation stage of basidiospores seems to be decisive, since mature basidiospores are more impermeable (Mims, 
1980; Martin et al., 1999; Campos \& Costa, 2010b). The tested basidiospores should represent propagules at different stages of development due to the structure of basidiocarps, which does not ensure the collection of material in a single development stage. This fact is highlighted by data from Campos \& Costa (2010b), who observed that, even in a single peridiole, the development of basidiospores may be asynchronous. The results obtained in the present study indicate the need to standardize the permeabilization treatment for each basidiocarp collected.

It was possible to verify a reduction in the hydrophobicity of basidiospores after treatment with bleach, especially at concentration of $50 \%$ for $40 \mathrm{~s}$ (data not shown). The presence of hydrophobic compounds in the wall of $P$. microcarpus basidiospores is known, hindering the production of suspensions of spores and, possibly, the entry of germinationstimulating compounds (Costa, 2002; Pereira, 2004). The presence of hydrophobins in hyphae, spores and ectomycorrhiza of Pisolithus and other fungi has already been reported (Martin et al., 1997; Tagu et al., 2000; Gow et al., 2017).

The percentages of basidiospores with the permeabilized cell wall reported in this study differed from those found by Godinho (2011), who reported permeabilization percentages ranging from 51 to $97 \%$ as a function of concentration and time of exposure to sodium hypochlorite. Moreover, in the work of Godinho (2011), mature basidiospores were permeabilized from the concentration equivalent to $2.5 \%$ bleach, with a contact time of $10 \mathrm{~s}$, which was not observed in the present study. The difference in permeabilization percentages may result from the morphophysiological variation between different basidiocarps, collected at different sites and times, as demonstrated here.

Alterations of the spicules contained in the last layer of the cell wall of permeabilized basidiospores were observed. These changes were more intense at the highest bleach concentration used, $50 \%$, with exposure time of $40 \mathrm{~s}$, a condition that led to partial or total loss of spicules. Possibly, these alterations of the cell wall may be associated with losses of viability of the basidiospores observed at this concentration, given the importance of this structure for the performance of functions that are vital to the physiology of the fungus, such as protection against changes in the osmolarity conditions of the medium and in the cellular signaling (Albertsheim \& Prouty, 1975; Schoffelmer et al., 1999; Bowman \& Free, 2006; Gow et al., 2017).

The cell wall of $P$. microcarpus was similar to that of $P$. tinctorius (Mims, 1980), with a cell wall consisting of four layers, the outermost, $\mathrm{L}_{1}$, electrondense with spicule-like ornamentations on its surface, followed by an electron-transparent inner layer, $\mathrm{L}_{2}$. The third layer, $\mathrm{L}_{3}$, is also electron-dense, and the innermost layer, $\mathrm{L}_{4}$, is electron-transparent. The combination of the methodologies used by Mims and Thurston (1979) and Webster (2007) with microwave processing allowed the preparation and observation of non-permeabilized basidiospores. In the process of basidiosporogenesis, the outermost layer of cell wall develops first and the other layers progress as the basidiospore matures (Mims, 1980; Campos $\&$ Costa, 2010b). As the layers of the cell wall are deposited, the basidiospores of $P$. tinctorius become increasingly difficult to be prepared for transmission electron microscopy analysis (Mims, 1980), due to the reduction of wall permeability. Similarly, mature basidiospores of $P$. microcarpus are impermeable to stains, making it difficult to observe nuclei or reserve materials by light or fluorescence microscopy (Costa, 2002; Campos \& Costa, 2010a; Campos \& Costa, 2010b; Godinho, 2011). The data obtained in this study constitute the first report of the structural conformation of the cell wall of $P$. microcarpus basidiospores.

After permeabilization with $5 \%$ bleach for 40 s, $80 \%$ of the permeabilized spores were viable. These data differ from those of Godinho (2011), who obtained maximum viability $(80 \%)$ with bleach at a concentration equivalent to $2.5 \%$ for $40 \mathrm{~s}$. The results obtained show the need to standardize the permeabilization procedure for each basidiocarp to be used experimentally.

The first colonies of $P$. microcarpus from the basidiospores with permeabilized cell wall appeared between the 15th and 18th day of incubation of the basidiospores in the presence of the host plant $C$. citriodora. In previous studies on in vitro germination of non-permeabilized Pisolithus spp. basidiospores, in the presence of different host plants, fungal colonies appeared between 16 and 70 days of incubation (Kope \& Fortin 1990; Carvalho et al., 1997; Costa, 2002; Pereira, 2004). Possibly, this variation is due

Revista Árvore 2021;45:e4509 
to the different cultivation conditions used. Fungal colonies emerged close to the roots of the host plant, indicating that germination is dependent on the release of stimulating compounds by the root (Fries, 1981; Carvalho et al., 1997; Costa, 2002; Pereira, 2004).

After the treatment of permeabilization with bleach, some basidiospores preserved the capacity to germinate. However, although the emergence of fungal colonies was observed after two weeks, the percentage of germination was low, $0.001 \%$. This value is similar to those reported by Costa (2002) and Pereira (2004) and indicates that the permeabilization treatment alone was not able to improve the germination percentages of $P$. microcarpus basidiospores.

\section{CONCLUSIONS}

Basidiospores from different basidiocarps have different susceptibilities to the treatment of permeabilization with bleach, highlighting the need to adjust the protocol for each fungal fruiting body. The treatment of basidiospores with bleach causes changes in the ultrastructure of the outermost layer of the cell wall, reducing or eliminating spicules. It was possible to obtain fungal colonies from the germination of permeabilized basidiospores, but the germination percentage was low, indicating that other factors besides the permeability of the spore wall are fundamental for the germination process.

\section{AUTHOR CONTRIBUTIONS}

MDC, JES, MRT, and MAMS conceived and planned the experiments. MAMS conducted the experiments and wrote the manuscript with inputs from MDC, JES, and MRT. JMN prepared figures and provided inputs to the discussion. All authors provided critical feedback on the manuscript.

\section{ACKNOWLEDGMENTS}

The authors express their gratitude to Fundação de Amparo à Pesquisa do Estado de Minas Gerais, FAPEMIG (Project number APQ-00288-08), Coordenação de Aperfeiçoamento de Pessoal de Nível Superior, Capes, (Finance code 001), and Conselho Nacional de Desenvolvimento Científico e Tecnológico, CNPq, for providing funds as well as graduate and research scholarships for the conduction of this work.

\section{REFERENCES}

ABRAF. Anuário estatístico ABRAF 2013 ano base 2012 / ABRAF. - Brasília: 2013. 148 p. : il. color; 21 $\mathrm{cm}$.

Adner N, Zetterlund A. Sanitization of Bio Pilot System and Columns Using Sodium Hydroxide. Technical Note 203. Uppsalla (SE): Amersham Biosciences; 2002.

Albertsheim P, Prouty AJ. Carbohydrates, proteins, cell surfaces, and the biochemistry of pathogenesis. Annual Review Plant Physiology. 1975; 26:31-52. doi: 10.1146/annurev.pp.26.060175.000335

Bowman SM, Free SJ. The structure and synthesis of the fungal cell wall. BioEssays. 2006; 28:799-808. doi: 10.1002/bies.20441

Campos ANR, Costa MD. Basidiosporogenesis, meiosis, and post-meiotic mitosis in the ectomycorrhizal fungus Pisolithus microcarpus. Fungal Genetics and Biology. 2010a; 47:477-483. doi: $10.1016 /$ j.fgb.2010.02.008

Campos ANR, Costa, MD. Histochemistry and storage of organic compounds during basidiosporogenesis in the ectomycorrhizal fungus Pisolithus microcarpus. World Journal of Microbiology and Biotechnology. 2010b; 26:17451753. doi: $10.1007 / \mathrm{s} 11274-010-0353-3$

Carvalho D, Rosado SCS, Souza AM, Oliveira AF. Produção de culturas monocarióticas e compatibilidade sexual intra e interpopulacional para o fungo ectomicorrízico Pisolithus tinctorius. Cerne. 1997; 3:143-160.

Costa MD, Borges AC, Kasuya MCM, Queiroz MV. Physiology and genetics of ectomycorrhiza formation in the Pisolithus-Eucalyptus symbiosis. In: Alvarez VH, Schaefer, CEGR, Barros, NF, editors. Tópicos em Ciência do Solo - Vol. II. Viçosa: SBCS. 2002; p.143-193. ISBN 15193934.

Estrela C, Estrela CRA, Hollanda AGB, Decurcio DA, Pécora JD. Influence of iodoform on antimicrobial potential of calcium hydroxide. Journal of Applied Oral Science. 2006; 14:33-37. doi: $10.1590 / \mathrm{S} 1678-77572006000100007$

Fries N, Birraux D. Spore germination in Hebeloma 
stimulated by living plant roots. Experientia. 1980; 36:319-324. doi: 10.1007/BF01965965

Godinho CS. Compostos de reserva e permeabilização de basidiósporos de Pisolithus microcarpus. 2011.

Gow NAR, Latge JP, Munro CA. The fungal cell wall: structure, biosynthesis, and function. Microbiol Spectrum. 2017; 5:FUNK-0035-2016. doi:10.1128/ microbiolspec.FUNK-0035-2016.

Instituto Nacional de Metereologia - INMETRO. Água Sanitária: Produto e segurança da embalagem. 2012. [acessado: 25 jun.2012]. Disponível http:// www.inmetro.gov.br

Kope HH, Fortin JA. Germination and comparative morphology of basidiospores of Pisolithus arhizus. Mycologia. 1990; 82:350-357. doi: $10.1080 / 00275514.1990 .12025890$

Martin F, Diez J, Dell B, Delaruelle C. Phylogeography of the ectomycorrhizal Pisolithus species as inferred from nuclear ribosomal DNA ITS sequences. New Phytologyst. 2002; 153:345-57. doi: 10.1046/j.0028-646X.2001.00313.x

Martin F, Lapeyrie F, Tagu D. Altered gene expression during ectomycorrhizal development. In: Carroll, Tudzynski editors The Mycota V Part A Plant relationships. Berlin: Springer-Verlag. 1997. p.223-242. ISBN 978-3-662-10372-2

Martin F, Laurent P, Carvalho D, Voiblet C, Balestrini R, Bonfante $\mathrm{P}$, et al. Cell wall proteins of the ectomycorrhizal basidiomycete Pisolithus tinctorius: identification, function, and expression in symbiosis. Fungal Genetics and Biology. 1999; 27:161-174. doi: 10.1006/fgbi.1999.1138

Marx DH. The influence of ectotrophic mycorrhizal fungi on the resistance or pine roots to pathogenic infection. I. Antagonism of mycorrhizal fungi to root pathogenic fungi and soil bacteria. Phytopathology. 1969; 59:153-63.

Mims CW, Thurston EL. Ultrastructure of teliospore formation in the rust fungus Puccinia podophylli. Canadian Journal of Botany. 1979; 57:2533-2538. doi: 10.1139/b79-301

Mims CW. Ultrastructure of basidiospores of the mycorrhizal fungus Pisolithus tinctorius. Canadian
Journal of Botany. 1980; 58:1525-1533. doi: 10.1139/b80-186

Pereira GMD. Germinação “in vitro" de esporos de Pisolithus sp. 2004.

Pereira MF, Campos ANR, Anastácio TC, Morin E, Brommonschenke SH, Martin F, et al. The transcriptional landscape of basidiosporogenesis in mature Pisolithus microcarpus basidiocarp. BMC Genomics. 2017; 18:157. doi 10.1186/s12864-0173545-5

Ruiz-Herrera J, Leon C, Carabez-Trejo A, ReyesSalinas E. Structure and chemical composition of the cell walls from the haploid yeast and mycelial forms of Ustilago maydis. Fungal Genetics and Biology. 1996; 20:133-142. doi: 10.1006/fgbi.1996.0028

Ruiz-Herrera J, Ortiz-Castellanos L. Cell wall glucans of fungi. A review. The Cell Surface. 2019; 5:100022. doi 10.1016/j.tcsw.2019.100022

Schoffelmer EAM, Klis FM, Sietsma JH, Cornelissen BJC. The cell wall of Fusarium oxysporum. Fungal Genetics and Biology. 1999; 27:275-282. doi: 10.1006/fgbi.1999.1153

Siqueira Jr JF, Lopes HP. Mechanisms of antimicrobial activity of calcium hydroxide: a critical review. International Endodontic Journal. 1999; 32:361-369. doi: 10.1046/j.1365-2591.1999.00275.x

Smith SE, Read DJ. Mycorrhizal symbiosis. Great Britain: Academic press. 2010. p.800. ISBN 978-012-370526-6

Tagu D, Lapeyrie F, Ditengou F, Lagrange H, Laurent P, Missoum N, et al. Molecular aspects of ectomycorrhiza development. In: Podila GK, Douds DD Jr, editors. Current Advances in Mycorrhizae Research. France: The American Phytopathological Society. 2000. p. 69- 89. ISBN 0-89054-245-7

Van der Heijden MGA, Martin FM, Selosse M-A, Sanders IR. Mycorrhizal ecology and evolution: the past, the present, and the future. New Phytologist. 2015; 205: 1406-1423. doi: 10.1111/nph.13288

Vries OMH, Fekkes MP, Wösten HA, Wessels JGH. Insoluble hydrophobin complexes in the walls of Schizophyllum commune and other filamentous fungi. Archives of Microbiology. 1993; 159:330-335. 
doi: 10.1007/BF00290915

Webster P. Microwave-assisted processing and embedding for transmission electron microscopy.

Methods in Molecular Biology. 2007; 396: 47-65.

doi: 10.1007/978-1-59745-294-6_42, p. 143-193 